\title{
QIBLA DIRECTION WITH THE CONSTELLATION (STUDY OF DETERMINATION OF QIBLA DIRECTION WITH GUBUG PENCENG)
}

\author{
M. Ihtirozun $\mathcal{N i}$ 'am $^{1}$, Nizma $\mathcal{N} u r$ Rahmi², Fiki Burhanuddin ${ }^{3}$ \\ ${ }^{1}$ Universitas Islam Negeri Walisongo, Semarang, ${ }^{2}$ Universitas Islam Negeri Walisongo, \\ Semarang, ${ }^{3}$ Institute for Sains and Religion Study \\ 1.1htirozun n@walisongo.ac.id, 르izmanurrahmi6@gmail.com, \\ muhammadfikky2000@gmail.com
}

\begin{abstract}
In the ethnography of Javanese society, Gubug penceng is used as a southern constellation. With a declination value of $-63^{\circ} 05^{\prime} 57^{\prime}$, the appearance of this gubug penceng is a bit unique, because it can only be observed by observers who are south of the tropic. However, with a magnitude value of 0.77 and a shape that is easy to remember, it makes the gubug becomes a star that is easily visible to the naked eye. The author here will examine the use of the gubug penceng for determining the direction of the Qibla. Previous writers will take into account the azimuth of the Qibla and the azimuth of the acrux star which is the brightest star in the constellation of the thinner, then determine the direction of the Qibla by referring to the difference between the azimuth acrux and the qibla. This research is a field research which is included in qualitative numerical research. The author will compare the results of the Qibla direction from this gubug penceng with the Qibla direction determined with the help of the azimuth of the Sun. The results of this study found that the gubug penceng can be used as a reference to determine the direction of the Qibla. The qibla direction of the measurement results is quite accurate, because the object of aiming is in the form of a central point of the star. The difference between the direction of the Qibla between using the reference hut is not more than 24 minutes, so the results are quite accurate.
\end{abstract}

Al-Hilal: Journal of Islamic Astronomy, Vol. 2, No. 2, Tahun 2020

p-ISSN : 2775-1236 ; e-ISSN : 2775-2119 


\title{
Abstrak
}

\author{
Keywords: Qibla Direction, Gubug Penceng, Acrux, Accurate
}

Gubug Penceng dalam etnografi masyarakat Jawa dipakai sebagai rasi bintang penunjuk arah selatan. Dengan nilai deklinasi sebesar $-63^{\circ} 05^{\text {ee }} 57^{\prime}$, kemuculan gubug penceng ini agak sedikit unik, karena hanya bisa diamati oleh pengamat yang berada di sebelah selatan garis balik utara. Namun demikian, dengan nilai magnitudo sebesar 0,77 dan bentuknya yang mudah diingat, membuat Gubug penceng menjadi bintang yang mudah diamati oleh mata telanjang sekalipun. Penulis di sini akan mengkaji pemakaian gubug penceng untuk penentuan arah kiblat. Penulis sebelumnya akan memperhitungkan nilai azimuth kiblat dan azimuth bintang acrux yang merupakan bintang terang di rasi gubung penceng, baru kemudian ditentukan arah kiblatnya dengan mengacu selisih azimuth acrux dengan kiblat. Penelitian yang dilakukan ini adalah penelitian lapangan (field research) yang termasuk ke dalam peneltian kualitatif numerik. Penulis akan membandingkan hasil arah kiblat dari gubug penceng ini dengan arah kiblat yang ditentukan dengan bantuan azimuth Matahari. Hasil dari penelitian ini ditemukan bahwa gubug penceng bisa dipakai acuan untuk menentukan arah kiblat. Arah kiblat hasil pengukiurannya pun cukup akurat, karena objek pembidikannya berupa satu titik pusat bintang. Selisih arah kiblat antara memakai acuan gubug penceng jika dibandingkan dengan memakai acuan azimuth Matahari tidak lebih dari $0^{\circ} 24^{\prime}$, sehingga bisa dikatakan bahwa hasilnya cukup akurat.

Kata Kunci : Arah Kiblat, Gubuk Penceng, Acrux, Akurat

\section{A. Introduction}

In determining the direction of the Qibla, there are several methods commonly used in Indonesia. Among them by using the rubu mujayyab calculation method, the right triangle method from the sun's shadow at any time, or the Rasdhul Qibla. seen from the tools it uses, there are various variants of the tools used, including: Rubu Mujayyab, ${ }^{1}$ Kompas, ${ }^{2}$ Mizwala, ${ }^{3}$ Istiwaain's Stick, ${ }^{4}$ al-Murobba and others. Apart from these methods, there are many other methods that can be studied and developed as options or alternative ways of determining the direction of the Qibla.

\footnotetext{
${ }^{1}$ Rubu Mujayyab is a calculating tool in the form of a quarter circle, so it is also known as the Kuadrant which means "quarter". This rubu is very useful for calculating the goneometric function and is useful for projecting the circulation of celestial bodies in the vertical plane.

${ }^{2}$ Kompass is a tool of wind direction using the hour hand contained in it. The use of this compass tool is still inaccurate, because the compass still uses a magnetic needle, so it can still be influenced by the varying magnetic power in each region.

${ }^{3}$ Mizwala is a practical tool by Hendro Setyanto, M.Si to determine the direction of the Qibla practically using sunlight. Mizwala is a modification of the Sundial form.

${ }^{4}$ Istiwa stick is an upright stick used to determine the direction of the Qibla with the help of a flat plane.
}

Al-Hilal: Journal of Islamic Astronomy, Vol. 2, No. 2, Tahun 2020

p-ISSN : 2775-1236; e-ISSN : 2775-2119 
Basically, any celestial body can be used for determining the direction of the Qibla provided that the object can be found and its azimuth value is known. After the azimuth value is known it is not difficult to find the azimuth value of the Qibla, because both have abscissa values in the horizon coordinates.

From the perspective of Syar'i, Ulama agree that the legal requirement for prayer is facing the Qibla, meaning that the law facing the Qibla is obligatory for Muslims. For people who don't know the direction of the Qibla, they can do ijtihad to find out the direction of the Qibla. Ijtihad can be in the form of calculating the direction of the Qibla, seeing from the surrounding environment that can be used as a direction, using the shadow of the Sun, or using instructions in the form of the Moon, Planet, or the azimuth of the Star at night .

At night, it seems as if our earth has a roof and is decorated with a thousand stars. At night, we can observe the constellations for directions. Among the constellations that are commonly used as directional directions are the dipping constellation to indicate north, the scorpio constellation to indicate the east, the dipping constellation to indicate west, and the kite constellation to indicate south. ${ }^{5}$ Javanese people know this kite constellation by the name of the gubug penceng. It is called the gubug penceng because the star arrangement seems to form an oblique hut (in Javanese it is called penceng). The author here is interested in examining this gubug penceng as a reference in determining the direction of the Qibla. In this case, there is one star that is bright enough to be a reference in determining its direction, that's Acrux.

There are several previous studies that discuss determining the direction of the Qibla using a reference to a star or planet. M. Ali Romdhon in his writing entitled "Study of Analysis of Using Stars as Indicators of the Qibla of Fishermen (Case Study of the Fishermen Group" Mina Kencana "Jambu Village, Mlonggo District, Jepara Regency)" explained that the fisherman used a long star as a pointer to the Qibla direction by looking

\footnotetext{
${ }^{5}$ Winardi Sutantyo, “Bintang Bintang Di Alam Semesta,” Penerbit ITB, Bandung, 2010.
} 
directly without binoculars or telescope aids.and the evening star is a planet, the planet Venus. ${ }^{6}$

Abdullah Sampulawa in his article "Determining the Direction of the Qibla using the Azimuth Planet", explains that the Planet azimuth method can be used as an alternative reference for determining the direction of the Qibla at night and the accuracy of the measurement of the Qibla direction is very accurate as using the Sun reference. ${ }^{7}$

Imam Sarujji in his writing "Determining the Direction of the Qibla using the Azimuth of the Stars and Planets", explained that determining the direction of the Qibla using the azimuth of the stars and planets is a method of determining the direction of the Qibla based on the position of any star and planet. and this method can be an alternative to determine the accurate Qibla direction. ${ }^{8}$

As for the tools used in determining the direction of the Qibla, there are several related studies, including Fahrin's writing with the title: "Qibla Laser as a Tool to Determine the Direction of the Qibla at Any Time Using the Sun and Moon". He explained that the method of determining the direction of the Qibla using the Qibla Laser and the concept of determining the direction of the Qibla with this tool basically uses the principles of calculating the azimuth of the Qibla, the angle of time, the azimuth of the Sun and true North. After being tested, this tool is a fairly accurate tool for determining the Qibla direction. ${ }^{9}$

\footnotetext{
${ }^{6}$ M Ali Romdhon, "Studi Analisis Penggunaan Bintang Sebagai Penunjuk Arah Kiblat Nelayan (Studi Kasus Kelompok Nelayan 'Mina Kencana’ Desa Jambu Kecamatan Mlonggo Kabupaten Jepara)” (IAIN Walisongo, 2012).

${ }^{7}$ Abdullah Sampulawa, "Penentuan Arah Kiblat Menggunakan Azimuth Planet" (Skripsi Fakultas Syari'ah dan Hukum UIN Walisongo Semarang, 2016).

${ }^{8}$ Imam Sarruji, "Penentuan Arah Kiblat Menggunakan Azimuth Bintang Dan Planet," Skripsi 147 (2016): $11-40$.

${ }^{9}$ Fahrin Fahrin, "Qibla Laser Sebagai Alat Penentu Arah Kiblat Setiap Saat Dengan Menggunakan Matahari Dan Bulan” (IAIN Walisongo, 2014).
}

Al-Hilal: Journal of Islamic Astronomy, Vol. 2, No. 2, Tahun 2020

p-ISSN : 2775-1236 ; e-ISSN : 2775-2119 
Muhammad Adieb's writing, with the title: "Comparative Study of Determining the Direction of the Qibla Istiwaaini by Slamet Hambali with Theodolite". From this study it was found that the difference between the two was not very far away, so it could be said that Istiwaaini was a tool to measure the Qibla direction that was suitable to use. ${ }^{10}$

Suwandi's writing entitled: "Analysis of the Use of the Nikon NE-102 Theodolite with the Two Point Method as Determining the Direction of the Qibla". The findings of this study indicate that the two-point method is one method of determining the direction of the Qibla based on the assumption that the Earth is ellipsoid. The comparison results of using theodolite with the two-point vincety method and the spherical triangle method in the actual measurement there are differences ranging from $0^{\circ}$ to $0^{\circ} 4115.06$.

Nur Hidayatullah's writing entitled Determining the Direction of the Qibla with Wind Blows (Fiqh and Science Perspective), that determining the direction of the Qibla using wind gusts can be used by knowing the coordinates of the place, air temperature and air temperature when measuring the Qibla and other required data. This qibla direction determination using wind gusts is alternative, not allowed to be used except in emergencies and urgency, because the accuracy value is quite weak .

As for other research on the direction of the Qibla and its relationship with outer space, there is the writing of M. Ihtirozun Niam, with the title: "Qibla Direction on Mars", where the direction of the Qibla for people on Mars is the direction of the Earth or the projection of the direction of the Earth, because in The earth of the Kakbah is located. How to find out by calculating and seeing the direction or azimuth of the Earth from the planet Mars. ${ }^{11}$

From existing research, studies revolve around determining the direction of the Qibla with celestial bodies, either the Sun, Moon, or with various tools that can be used. Here the author will discuss more specifically the determination of the direction of the

\footnotetext{
${ }^{10}$ Muhammad Adieb, "Studi Komparasi Penentuan Arah Kiblat Istiwaaini Karya Slamet Hambali Dengan Theodolite" (IAIN Walisongo, 2014).

${ }^{11}$ M Ikhtirozun Ni'am, "Arah Kiblat Di Planet Mars," Al-Marshad: Jurnal Astronomi Islam Dan Ilmu-Ilmu Berkaitan 2, no. 1 (2017).
} 
Qibla using the gubug penceng's constellation by utilizing the azimuth of one of its bright stars, the acrux star.

\section{B. Method}

This research is a field research. The research method used in this research is qualitative numerical with a descriptive approach. The author will describe a new method in determining the direction of the Qibla using this gubug penceng's constellation, especially the azimuth of the star Acrux. ${ }^{12}$ Then the author will analyze the accuracy of the calculation results and the measurement of the Qibla direction compared to using the azimuth of the Sun.

The author made observations in two places: the Kongkow Carsem BPI shop with south latitude -6 5933.3 " and east longitude 110 21 22.2" and the Rukmini's boarding house in Ringinsari 2 with latitude coordinates of -6 5938 " south latitude and east longitude $110^{\circ} 2102.2 "$. This place was chosen by the writer because it can see directly to the south and its position is high enough so that it is easy to see the gubug penceng's constellations.

\section{Discussion and Results}

\section{C.1. Qibla Direction and It's Legal Basis}

Qibla in language is the direction, as what is meant here is the ka'bah. This is as expressed by Muhammad Al Katib Al Asyarbini, as quoted by Slamet Hambali in his book:

\section{والقبلة فى اللغة : الجهة والمراد هنا الكعبة}

"And the Qibla in the language is the direction and what is meant here is the Kakbah"13 The word qibla comes from Arabic, which is جهة موا وجهة which means the direction at hand. Then the understanding is devoted to a direction, where all those who offer prayers face that direction .

${ }^{12}$ Prof Sugiyono, "Memahami Penelitian Kualitatif," Bandung: Alfabeta, 2005.
${ }^{13}$ Slamet Hambali, Ilmu Falak (Semarang: UIN Walisongo, 2018).

Al-Hilal: Journal of Islamic Astronomy, Vol. 2, No. 2, Tahun 2020

p-ISSN : 2775-1236 ; e-ISSN : 2775-2119 
The word Qibla in the Qur'an has many meanings, including direction. The word Qibla which means direction (Qibla) as mentioned in the Koran in the letter Al-Baqoroh verse 142 :

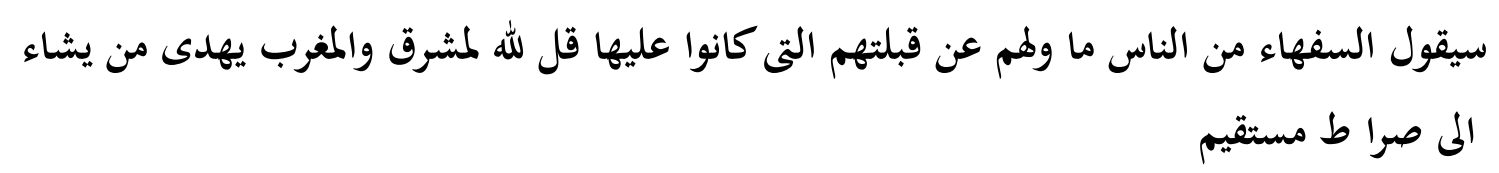

People who are less resourceful among humans will say: "What turned them (Muslims) from their Qibla (Baitul Maqdis) which they had previously oriented to him?" say: "To Allah's East and West, He instructs whom He wills to the straight path." ${ }^{14}$ (Surah Al Baqoroh verse 142)

According to the term, talking about the Qibla is talking about the direction to the Ka'bah. The scholars vary in providing definitions of the direction of the Qibla, even though it is basically based on one object of study, namely the Ka'bah. ${ }^{15}$

Muhyiddin Khazin states in his book that the direction of the Qibla is the direction or the closest distance along the large circle that passes through the city of Makkah (Ka'bah) to the place of the city in question, such as Jakarta, where the direction closest to Makkah is westward oblique to the north. ${ }^{16}$ Meanwhile, according to Ahmad Izzuddin, the Qibla is the closest direction from a person to the Ka'bah and every Muslim is obliged to face him while praying. ${ }^{17}$

Ministry of Religion of the Republic Indonesia defines it as a certain direction for Muslims to direct their faces in performing prayers and according to Slamet Hambali that the direction of the Qibla is the direction to the Ka'bah (Makkah) through the nearest route where every Muslim praying must face that direction. ${ }^{18}$

\footnotetext{
${ }^{14}$ Departemen Agama Ri, “Al-Qur’an Dan Terjemahnya,” Semarang: Toha Putra, 1989.

${ }^{15}$ Ahmad Izzuddin, Ilmu Falak Praktis: Metode Hisab-Rukyat: Praktis Dan Solusi Permasalahannya (Pustaka Rizki Putra, 2012).

${ }^{16}$ Muhyiddin Khozin, "Ilmu Falak Dalam Teori Dan Praktik" (Yogyakarta: Buana Pustaka, 1996).

${ }^{17}$ Izzuddin, Ilmu Falak Praktis: Metode Hisab-Rukyat: Praktis Dan Solusi Permasalahannya.

${ }^{18}$ Slamet Hambali, "Ilmu Falak," Semarang: Program Pascasarjana IAIN Walisongo Semarang, 2011.
} 
Abdul Aziz Dahlan and his friends defined the Qibla as the building of the Kaaba or the direction that the Muslims are aiming for in carrying out part of the Worship. ${ }^{19}$ Harun Nasution and his friends in the Islamic Law Encyclopedia interpreted that the Qibla is the direction facing the prayer time. ${ }^{20}$ From the various definitions above, it can be concluded that the Qibla is the closest direction from a person to the Ka'bah and every Muslim is obliged to face the Qibla when performing prayers.

Facing the Qibla is one of the valid requirements for prayer. This is based on the following verse:

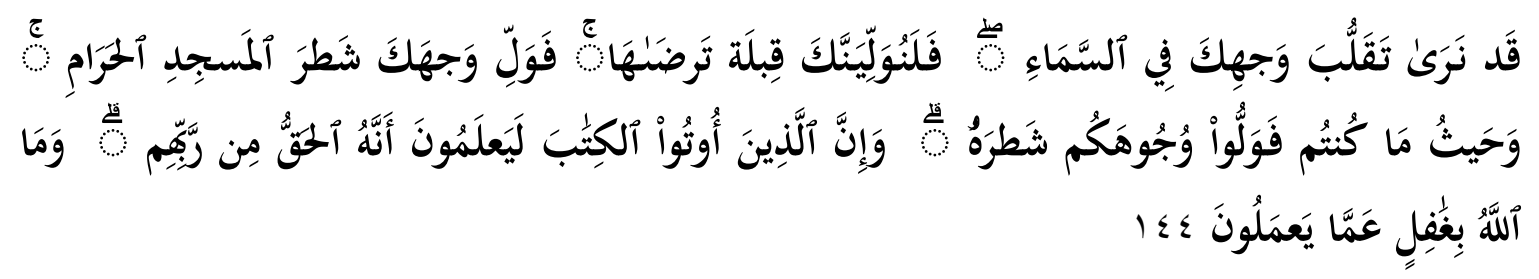

"We see your face (Muhammad) often looks up to the sky, then We will turn you to the Qibla that you like. Therefore, face your face towards the Grand Mosque. Wherever you are, turn your face in that direction. In fact, the People of the Book know that moving the Qibla is the truth from God.”(Al-Baqarah:144)

In accordance with the arguments described above, that in order to pray, it is mandatory to face the Qibla in accordance with the coordinates of the place. Apart from being obliged to face the Qibla during prayer, we are also obliged to face the Qibla when praying after ablution, and other worship activities ${ }^{21}$ such as when reading the Al-Quran, praying, dzikr, and others. ${ }^{22}$

Ulama have agreed that anyone who prays around the Grand Mosque and sees the Ka'bah directly, it is obligatory for him to face the Ka'bah (ainul Kabah) directly. However, if the person is far from the Grand Mosque, Ulama differ on this matter. According to

\footnotetext{
${ }^{19}$ Abdul Aziz Dahlan, “Ensiklopedi Hukum Islam,” Jakarta: Ichtiar Baru Van Hoeve, 1996.

${ }^{20}$ Harun Nasution, "Ensiklopedi Hukum Islam," Jakarta: Djambatan, 1992.

${ }^{21}$ https://www.eramuslim.com/thaharah/bagaimana-hukumberwudhu-tidak-menghadap-ke-arahkiblat.htm, accessed on 10 December 2017 at 18.30 WIB

${ }^{22}$ Muh Sudibyo, "Sang Nabipun Berputar: Arah Kiblat Dan Tatacara Pengukurannya," Solo: Tinta Media, 2011.
}

Al-Hilal: Journal of Islamic Astronomy, Vol. 2, No. 2, Tahun 2020

p-ISSN : 2775-1236 ; e-ISSN : 2775-2119 
Ulama Syafi'i and Hambali, it is obligatory to face the ainul Kabah. For people who cannot see the Ka'bah directly, then he must deliberately face the direction where the Ka'bah is even though in essence he only faces his jihat. ${ }^{23}$ Meanwhile, according to Ulama Hanafi and Maliki what is obligatory is sufficient jihatul Kabah, so for people who can watchThe Ka'aba is directly facing the ainul Ka'bah, if he is far from Mecca then it is enough to face him (not necessarily exactly), so it is enough to suspect that there is the Qibla.

\section{C.2. Types of Methods for Determining the Qibla Direction}

In determining the direction of the Qibla there are several methods used. In this context we are required to be careful, because the error of 10 in the measurement is equal to $111.11 \mathrm{Km}$. There are several kinds of methods including :

\section{1) Qibla Azimuth}

Qibla Azimuth is a circular arc of the horizon or horizon calculated from the North to the East (clockwise direction) to the Qibla point. where the north point of the azimuth is $0^{\circ}$, the east point of the azimuth is $90^{\circ}$, the south point of the azimuth is $180^{\circ}$, and the west point of the azimuth is $270^{\circ} .24$

\section{2) Rashdul Qibla}

Rashdul Qibla or what is commonly called the image of the Qibla direction is the image of every object that stands perpendicular to the surface of the earth coincides with the direction of the Qibla, so it shows directly towards the Qibla. For rashdul Qibla this occurs during the day because it uses the sun's shadow. ${ }^{25}$ Rashdul Qibla is divided into two, namely the image of the Qibla direction above the Ka'bah (global rashdul Qibla) and the image of the Qibla direction on the Ka'bah path (local rashdul Qibla).

\section{3) The Qibla Direction Using The Constellations}

\footnotetext{
${ }^{23}$ Abdurrahman bin Muhammad Awwad Al-Jaziry, “1699, Kitabul Fiqh 'Ala Madzahibil Arba'Ah” (Beirut: Dar Ihya'At Turats Al Araby, n.d.).

${ }^{24}$ Hambali, "Ilmu Falak," 2011

${ }^{25}$ Zainul Arifin, Ilmu Falak: Cara Menghitung Dan Menentukan Arah Kiblat, Rashdul Kiblat, Awal Waktu Shalat, Kalender Penanggalan, Awal Bulan Qomariyah,(Hisab Kontemporer) (Penerbit Lukita, 2012).
}

Al-Hilal: Journal of Islamic Astronomy, Vol. 2, No. 2, Tahun 2020 p-ISSN : 2775-1236 ; e-ISSN : 2775-2119 
It is possible to determine the direction of the Qibla using all celestial bodies, not only the sun. In this case, the most important thing is that the lanbit object has an azimuth value and can be observed. the ancients before the advanced navigation technology now, they determine the direction of the wind by the constellations. Orion constellation to indicate the direction of the West. Big Dipper to indicate the direction of North. Scorpio constellation to indicate the direction of the East. and the constellation kite or so-called hut penceng to determine the south direction. ${ }^{26}$ In matters of Qibla direction, it is not uncommon for them to use constellations. ${ }^{27}$

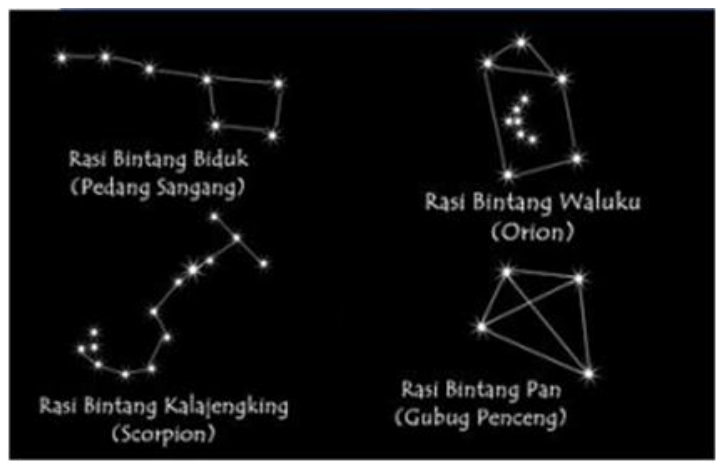

Pict.1. The picture of constellation directions

\section{C.3. Gubug Penceng's Constellation}

Gubug penceng's constellation ia a group of stars that are in a regionof the sky and have almost the same shape and appear close to each other. The sky is divided into eighty eight (88) constellation. The stars in the same area are one constellation. The previous person in determining a constellation saw the shape of the same stars, such as the scorpio constellation which resembled the shape of a scorpion, and others. ${ }^{28}$ The scorpion's constellation seems to form a scorpion image, because with single eyes we can see the star in the sky with the scorpio's head formed by four blue stars, while the tail is formed from a series of seven bright stars. ${ }^{29}$

\footnotetext{
${ }^{26}$ https://barripandapa.wordpress.com/2013/12/15/94/, accessed on $5^{\text {th }}$ December 2017 at 17.10 WIB.

${ }^{27}$ Hambali, Ilmu Falak, 2018.

${ }^{28}$ https://id.wikipedia.org/wiki/Rasi_bintang, accessed on 10 December 2017 at 20.15 WIB.

${ }^{29}$ Rohmat Haryadi, Ensiklopedia Astronomi Matahari dan Bintang, (Jakarta: Erlangga 2008), h. 36
}

Al-Hilal: Journal of Islamic Astronomy, Vol. 2, No. 2, Tahun 2020

p-ISSN : 2775-1236 ; e-ISSN : 2775-2119 
Each nation has its own envy, like the three stars lined up in the hunter's belt in the constellation Orion by the Javanese called "latitude waluku" or a plowing tool. This constellation coincides with the arrival of the rainy season in Indonesia. ${ }^{30}$ Similar to the constellation Crux by the Javanese it is called a "hut hut" where the shape of this constellation is the same as a kite .

\section{C.4. Gubug Penceng for Determining of Qibla Direction}

The constellation of gubug penceng in Indonesian is known as the kite constellation or in Latin known as Crux. The constellation of the Penceng Gubug is the stars in the southern hemisphere sky, where if we look at the southern hemisphere sky, we are facing the center of the galaxy, which is inhabited by very many stars. In Latin, the hut is called crux which means cross. commonly known as the Southern Cross (Southern Cross) which is the smallest constellation among the 88 modern constellations. This constellation is surrounded by Centaurus and to the south is Musca.

The name of gubug penceng comes from the island of Java, where from the story of a number of young people who are building a house, in front of a house that is being built every day by a beautiful woman who will deliver food to the fields. The beauty of the woman disturbs the youth's consensus. As a result, the house that was built had a slanted shape, aka crooked. The image was immortalized as the name of the penceng hut. In addition to this name, the crux constellation is named for the barn. Lumbung has the meaning of a place to store rice, which is one of the season markers (catelu prey) on the Pranatamangsa calendar. Besides that, the Bugis people know the constellation Crux with Bintoeng Bola Keppang which means a sloping house, once there was a carpenter who was building a house and a beautiful widow who often disturbed the carpenter and without realizing that the length of one of the pillarsthe house is cut not the same as the other posts.and in Wakatobi district, the Bajo people know it as Lalayah, which is a marker for

\footnotetext{
30 Sutantyo, "Bintang Bintang Di Alam Semesta."
} 
the South, and on the island of Sumatra the Malay community and the Malay Peninsula are known as Buruj Pari.

The stars contained in the constellation of the gubug penceng include:

\begin{tabular}{|c|c|c|c|c|}
\hline Name & Condidion & $\begin{array}{l}\text { Onether } \\
\text { Name }\end{array}$ & $\begin{array}{l}\text { Orgin Of } \\
\text { Language }\end{array}$ & The Meaning \\
\hline$\beta \mathrm{Cru}$ & 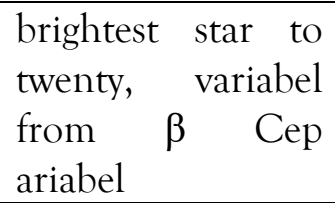 & $\begin{array}{l}\text { Mimosa, } \\
\text { Becrux }\end{array}$ & Latin & $\begin{array}{l}\text { Impersonator, } \\
\text { Abbreviations of "Beta" } \\
\text { and "Crux" }\end{array}$ \\
\hline$\alpha \mathrm{Cru}$ & $\begin{array}{l}\text { Double star, } \\
\text { brightest star to } \\
\text { twenty-three }\end{array}$ & $\begin{array}{l}\text { Acrux/ } \\
\text { Magalhãnica }\end{array}$ & $\begin{array}{l}\text { Latin/ } \\
\text { Portuguese }\end{array}$ & $\begin{array}{l}\text { Abbreviations of "Alpha" } \\
\text { and "Crux"/ Magellan } \\
\text { star }\end{array}$ \\
\hline$\gamma \mathrm{Cru}$ & Three-star system & $\begin{array}{l}\text { Gacrux/ } \\
\text { Rubidea }\end{array}$ & $\begin{array}{l}\text { Latin/ } \\
\text { Portuguese }\end{array}$ & $\begin{array}{l}\text { Abbreviations } \\
\text { "Gamma" d } \\
\text { and "Crux"/ } \\
\text { kemerahan }\end{array}$ \\
\hline$\delta \mathrm{Cru}$ & $\begin{array}{l}\text { Variabel from } \beta \\
\text { Cep } \\
\text { variable }\end{array}$ & Pálida & Portuguese & Pale \\
\hline$\varepsilon \mathrm{Cru}$ & & Intrometida & Portuguese & $\begin{array}{l}\text { Curiosity } \\
\text { (curious) }\end{array}$ \\
\hline
\end{tabular}

Table 1. Names of the stars in the constellation Gubug Penceng

Initially this constellation was not considered a constellation itself, but part of the constellation Centaurus. The discovery of the constellation Crux as a constellation itself was attributed to the French astronomer (Ausgustin Royer) in 1679. ${ }^{31}$

In the context of determining the direction of the Qibla using the constellation of this pennant hut, there is one star that is used as a benchmark through its azimuth calculation, namely the acrux star.

${ }^{31}$ https://id.wikipedia.org/wiki/Crux, accessed on $5^{\text {th }}$ December 2017 at 17.25 WIB.

Al-Hilal: Journal of Islamic Astronomy, Vol. 2, No. 2, Tahun 2020

p-ISSN : 2775-1236 ; e-ISSN : 2775-2119 


\section{C.5. Definition and Scope of the Acrux Star}

Acrux (a Cru / a Crucis / Alfa Crucis) is one of the stars in the constellation hut, Crux. Since the hut huts are located about 60 degrees below the celestial equator, they are only visible to the south of the Tropic of the Tropic of the Tropic. acrux has a magnitude of 0.77 and is the twelfth brightest star in the sky. This star is the southernmost star with the first magnitude and beat Rigil Centaurus (a Centauri). ${ }^{32}$

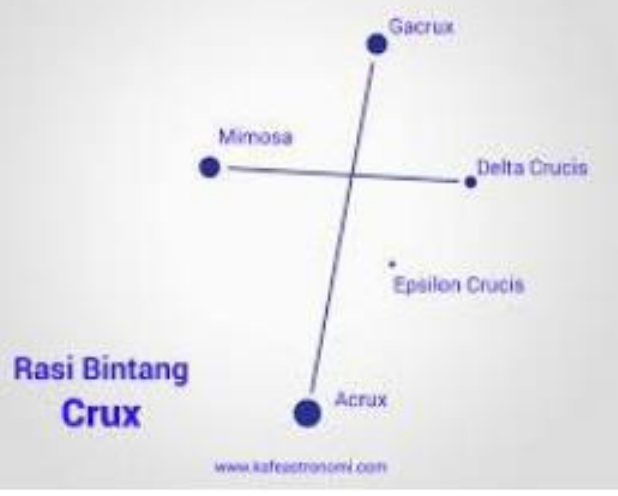

Pic.2. The picture of constellation Acrux

\begin{tabular}{cc}
\hline \multicolumn{2}{c}{ Observation Data } \\
\hline Constellation & Crux \\
\hline Asensio Rekta & $12 \mathrm{~h} 26 \mathrm{~m} \mathrm{35.9 \textrm {s }}$ \\
\hline Deklination & $-63^{\circ} 05^{\text {ee }} 57^{\prime \prime}$ \\
\hline Apperent Magnitudo & $1.40 / 2.09$ \\
\hline Table 2. Acrux Star Data &
\end{tabular}

For the world community, especially those in the southern region of the equator, the constellation Crux has an important meaning for their lives, where this constellation has a star formation resembling a rhombus or kite shape. the name of this constellation is

\footnotetext{
32 https://id.wikipedia.org/wiki/Acrux, accessed on 5th Desember 2017 at 20.00 WIB

${ }^{33} \mathrm{https} / / /$ id.wikipedia.org/wiki/Acrux, accessed on 5th Desember 2017 at 20.00 WIB
}

Al-Hilal: Journal of Islamic Astronomy, Vol. 2, No. 2, Tahun 2020 p-ISSN : 2775-1236; e-ISSN : 2775-2119 
very diverse, some call it the constellation of rays, constellations of kites, constellations of the hut, and others.

Acrux star is a bright star that has a blue and white star color and belongs to the star class BO, 5IV. in the world of navigation, sailors use Acrux Star as one of the navigation stars because this star is very easy for us to observe using the naked eye. The star Acrux has an apparent magnitude of +1.25 with a distance of 320.70 light years from our Earth. In plain view, the Acrux star appears as a single star, but this Acrux star has a three-star system. ${ }^{34}$

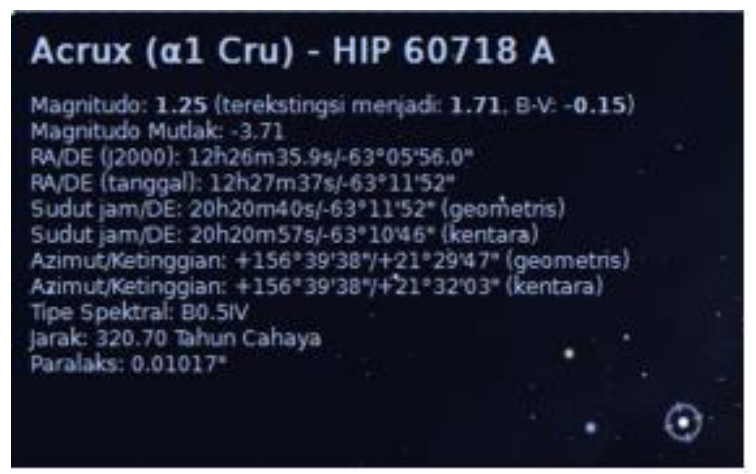

Pic.3. The Picture of Acrux Star ${ }^{35}$

a) Acrux Star locations

The location of stars in galaxies is determined by the values of Asensiorecta (RA) and Declination (Deck), these are equivalent to longitude and latitude on Earth. The ascension is how far in time (hh: $\mathrm{mm}$ : ss) the star is along the celestial equator. ${ }^{36}$ While the declination is how far North or South the star is calculated

\footnotetext{
${ }^{34}$ http://kafeastronomi.com/crux.html, accessed on 17 December 2017 at 15.50 WIB

${ }^{35}$ Stellarium Aplication

${ }^{36}$ Khozin, "Ilmu Falak Dalam Teori Dan Praktik."
}

Al-Hilal: Journal of Islamic Astronomy, Vol. 2, No. 2, Tahun 2020

p-ISSN : 2775-1236; e-ISSN : 2775-2119 
from the celestial Equator expressed in degrees. ${ }^{37}$ Acrux star location is $12 \mathrm{~h} 26 \mathrm{~m}$ 35.94 s and $-63 \mathrm{~d} 05^{\prime} 56.6{ }^{\prime 38}$

b) Acrux's precise movement

All stars are like planets orbiting around a center point, in the case of the main star planets like the Sun. In the case of the star at the center is the galaxy. the constellations we see today will be different from 50,000 years ago or 50,000 years now. The precise motion details the motion of these stars and is measured in millennia of seconds. the stars are moving -14.86 \pm 0.36 billioncseconds / year towards the North and $-35.83 \pm 0.50$ billioncseconds / year towards the East if we look at them on the horizon.

c) Physical properties (color, temperature, radius) of Acrux

Acrux has a BO.5IV spktrel type. this means it is a blue subgiant star. Its star is 7351.00000000 Parsesc from Galatic Center or the term Light Years is 23976.2674174400000000s. The star has a BV Color Index of -0.24 which means the temperature of the star has been calculated using information from Morgans@uni.edu to be 21,255 Kelvin .

The radius of the star Acrux has been calculated to be 4.74 times that of the Sun. The radius of the Sun is $695,800 \mathrm{~km}$, therefore the radius of the star is estimated at 3,299,945.35 km. This star has a companion star that is in close orbit. ${ }^{39}$

\footnotetext{
${ }^{37}$ Khozin, "Ilmu Falak Dalam Teori Dan Praktik."

38 https://translate.google.co.id/translate?hl=id\&sl=en\&u=https:/ www.universeguide.com/star/acr ux\& prev=search, accessed on 17 December 2017 at 16.05 WIB

${ }^{39} \mathrm{https}: / /$ translate.google.co.id/translate?hl=id\&sl=en\&u=https://www.universeguide.com/star/acrux\&pr ev=search, accessed on 17 December 2017 at 16.05 WIB
}

Al-Hilal: Journal of Islamic Astronomy, Vol. 2, No. 2, Tahun 2020 p-ISSN : 2775-1236; e-ISSN : 2775-2119 
Because basically the star produces its own energy through the fusion reaction mechanism contained in the core, so that the surface temperature is very hot. ${ }^{40}$

d) Acrux star observation

We can observe the Acrux star every year with a period. Where in April the constellation Crux will appear after sunset and will always appear in the Southern sky so that it sets when the sun rises. then right in October the constellation Crux was completely invisible in the night sky. The constellation Crux has a star formation resembling a kite or a rhombus. In the sky, the constellation Crux star rises from the southeast and is in the southern sky. To find out the rising and setting of the constellation Crux, you can calculate it yourself, using the Stellarium application or by manual calculations .

\section{C.5. Acrux Star Azimuth Manual Calculations}

On this occasion, the author will calculate the azimuth of the star using the data contained in the Nautica Almanac. In the Nautica Almanac there are several terms, including:

1) Dec (Declination) This marks the height above or below the equator for celestial bodies. Equivalent to latitude on earth.

2) GHA (Greenwich Hour Angle) shows the position across the plane of the Greenwich meridian measured in degrees. in the Nautica Almanac, where the GHA values are the Sun, Moon and Planets.

3) LHA (Local Hour Angle) is the angle between the meridian of a celestial body and the observer meridian. Where LHA = GHA celestial body + Observer longitude.

40 Encep Abdul Rojak, Amrullah Hayatudin, and Muhammad Yunus, "Koreksi Ketinggian Tempat Terhadap Fikih Waktu Salat: Analisis Jadwal Waktu Salat Kota Bandung,” Al-Ahkam 27, no. 2 (2017): $241-66$.

Al-Hilal: Journal of Islamic Astronomy, Vol. 2, No. 2, Tahun 2020

p-ISSN : 2775-1236; e-ISSN : 2775-2119 


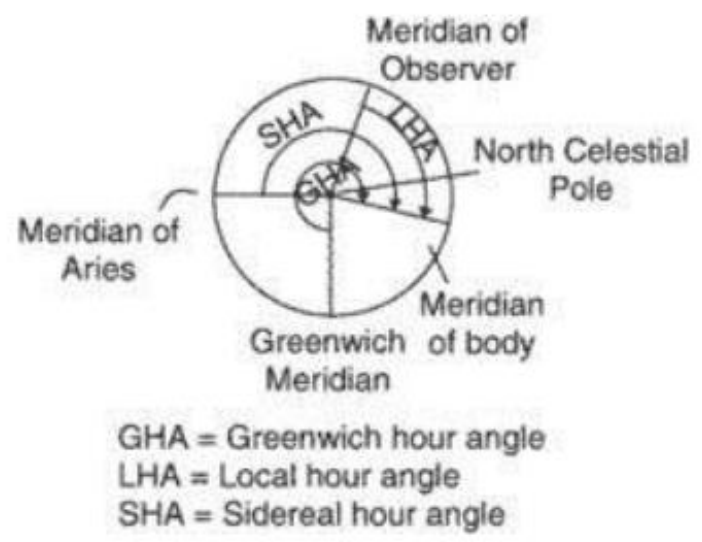

Pic.4. The Pictures of GHA, SHA and LHA ${ }^{41}$

4) SHA (Sidereal Hour Angle). Because the stars are fixed (they are not really fixed, but they are so far away that they don't move much), in Almank Nautica the only SHA indigo is the star. The SHA of the star is simply a coordinate relative to the point of Aries

$$
\text { So to calculate the GHA star }=\text { SHA star }+ \text { GHA Aries. }{ }^{42}
$$

An example of calculating the azimuth of the star Acrux on December 11, 2017 at 02.00 WIB at the Kongkow Carsem BPI shop with latitude -6o 59 '33.3 "LS and place longitude 110 21' 22.2" East Longitude and azimuth Qibla 294' 31 "02.25" UB. To calculate the azimuth for Acrux stars you can use several formulas and steps to find out the azimuth, including:

1) Calculate the time angle of the star

$$
\text { GHA star }=\text { SHA star }+ \text { GHA Aries }
$$

${ }^{41}$ https://encyclopedia2.thefreedictionary.com/Greenwich+hour+angle, accessed on 13 December 2017 at 09.10 WIB

${ }^{42}$ GHA Aries should not be any different from a star, but as Hipparchus noted long ago that the earth shakes, its axis is doing a full circle of about 26,000 years which means that the first point of Aries slowly drifts across the background of the star, making a full circlein 26,000 years. This is called the first point of Aries because it is the point where the sun crosses the equatorial plane on its way from the Southern hemisphere to the North (around March 21) and it happens to the fallen Zodiac sign Aries.

Al-Hilal: Journal of Islamic Astronomy, Vol. 2, No. 2, Tahun 2020 p-ISSN : 2775-1236 ; e-ISSN : 2775-2119 
LHA Star $=$ GHA Star + Place Longitude

Data:

To find data, the observation time is converted into UT time ${ }^{43}$

Almanac time $=$ observation time -7 hours ${ }^{44}$

$$
\begin{aligned}
& =02.00-7 \text { hours } \\
& =19.00 \mathrm{UT}
\end{aligned}
$$

Look at the Nautica Almanac, the data at 19.00 is obtained:

SHA star Acrux $=173^{\circ} 06.0^{\prime}$

The declination of the star Acrux $=-63^{\circ} 11.5^{\prime}$

$\mathrm{GHA}$ Aries $=4^{\circ} 41.5^{\mathrm{ec}}$

Data entered in the formula:

$$
\begin{aligned}
\text { GHA star } & =\text { SHA star }+ \text { GHA Aries } \\
& =173^{\circ} 06.0^{\circ e}+4 \circ 41.5^{c e} \\
& =177^{\circ} 47^{c e} 30^{\prime \prime} \\
\text { LHA Star } & =\text { GHA Star + Place Longitude } \\
& =177^{\circ} 47^{\prime} 30^{\prime \prime}+110^{\circ} 21^{\prime} 22.2^{\prime \prime} \\
& =288^{\circ} 08^{\prime} 52.2^{\prime \prime}
\end{aligned}
$$

2) Calculate the height of the star

\footnotetext{
${ }^{43}$ because in the Almanac Nautica uses UT time.

${ }^{44}$ for WIB, while for WITA it is reduced by 8 and for WIT is reduced by 9 .
}

Al-Hilal: Journal of Islamic Astronomy, Vol. 2, No. 2, Tahun 2020

p-ISSN : 2775-1236 ; e-ISSN : 2775-2119 
$\operatorname{Sin} h b=\sin \phi x \sin \delta b+\cos \phi x \cos \delta b \cos t b$

$$
\begin{aligned}
= & \sin -6^{\circ} 59^{\prime} 33.3^{\prime \prime} \sin -63^{\circ} 11.5^{\prime}+\cos -6^{\circ} 59^{\prime} 33.3^{\prime \prime} \cos -63^{\circ} 11.5^{\prime} \\
& \cos \mathrm{b} 288^{\circ} 08^{\prime} ' 52.2^{\prime \prime} \\
= & 14^{\circ} 21^{\prime} 51.52^{\prime \prime}
\end{aligned}
$$

3) Calculate the zenith distance of the star

$\operatorname{Cos} z \mathrm{mb}=\sin \phi \mathrm{x} \sin \delta \mathrm{b}+\cos \phi \mathrm{x} \cos \delta \mathrm{b} \cos \mathrm{tb}$

$$
\begin{aligned}
= & \sin -6^{\circ} 59^{\prime} 33.3^{\prime \prime} \sin -63^{\circ} 11.5^{\prime}+\cos -6^{\circ} 59^{\prime} 33.3^{\prime \prime} \cos -63^{\circ} 11.5^{\prime} \\
& \cos 288^{\circ} 08^{\prime} 52.2^{\prime \prime} \\
= & 75^{\circ} 38^{\prime} 08.48^{\prime \prime}
\end{aligned}
$$

4) Knowing the direction of the star and star azimuth

Cotan $\mathrm{Ab}=\tan \delta \mathrm{b} \cos \phi \mathrm{x}: \sin \mathrm{tb}-\sin \phi \mathrm{x}: \tan \mathrm{tb}$

$=\tan -63^{\circ} 11.5^{\prime} \cos -6^{\circ} 59^{\prime} 33.3$ ": $\sin 288^{\circ} 08^{\prime} 52.2^{\prime \prime}-\sin -6^{\circ} 59^{\prime} 33.3$ ": $\tan 288^{\circ} 08^{\prime}$ '52.2"

$=26^{\circ} 15^{\prime} 26.27^{\prime S T}$

To get Acrux star Azimuth you can use the following conditions:

If $\mathrm{Ab}=\mathrm{UT}(+)$, then Azimuth Star $=\mathrm{Ab}$ (fixed).

If $\mathrm{Ab}=\mathrm{UB}(+)$, then Azmiuth Star $=360^{\circ}-\mathrm{Ab}$.

If $\mathrm{Ab}=\mathrm{ST}(-)$, then Star Azimuth $=180^{\circ}-\mathrm{Ab}$. With $\mathrm{Ab}$ positivated .

If $\mathrm{Ab}=\mathrm{SB}(-)$, then Azimuth Star $=180^{\circ}+\mathrm{Ab}$. With $\mathrm{Ab}$ positivated 
5) Know the Azimut star Acrux

$$
\begin{aligned}
\text { Azimuth Star } & =180^{\circ}-\mathrm{Ab} \\
& =180^{\circ}-26^{\circ} 15^{\prime} 26.27^{\prime \prime} \\
& =153^{\circ} 44^{\prime} 33.73^{\prime} .
\end{aligned}
$$

\section{C.6. Star Azimuth Method And Its Calculation}

The method of determining the Qibla direction using the Acrux star azimuth is the same as determining the Qibla direction using the sun, because basically every celestial body can be used as a determination of the direction of the Qibla, as long as the azimuth value can be calculated. In this Acrux star azimuth method, we must first know the azimuth value of the Acrux star .

One of the differences in determining the direction of the Qibla using the Sun and the stars lies in the object being observed. Determining the direction of the Qibla using the Sun cannot be observed with the naked eye and what is seen is the reflection of the Sun's light. While determining the direction of the Qibla using a star can be seen with the naked eye or a tool such as Theodolite and what is seen is the focus of the star point.

This method of determining the direction of the Qibla using the Acrux star azimuth is another alternative when the weather is cloudy or rainy during the day. however, to determine the direction of the Qibla using the azimuth of the star Acrux, you must first ensure that the star is rising and can be observed. After that, it remains only to calculate the value of the azimuth difference between the azimuth of the Qibla and the star. in practice, the difference in the azimuth difference can be targeted using theodolite.

At the practical level, the steps for determining with Theodolita can be described as follows:

1) Installing the Theodolite, starting from a tripod and bada theodoliete in a completely perpendicular position in all directions by paying attention to the water pass on the theodolite.

Al-Hilal: Journal of Islamic Astronomy, Vol. 2, No. 2, Tahun 2020

p-ISSN : 2775-1236; e-ISSN : 2775-2119 
2) Check the battery that is installed, if it is not installed use a good battery on the theodolite.

3) Shoot for the stars according to the shooting time based on the zenith distance of the stars.

4) After the star is shot immediately the horizontal motion is locked, then zeroed.

5) Stargazing according to the time of sight is used as a reference to calculate the direction of the star and the azimuth of the star at that hour.

6) Calculating the distance to the Qibla direction from the position of the star or also known as the azimuth difference.

7) After knowing the azimuth difference, releasing the horizontal lock of the theodolite, then turning it to the right until the azimuth difference value is positioned, then the horizontal theodolite is locked again. Thus the theodolite is pointing towards the Qibla .

For example, if we already know the azimuth of the star Acrux 153 44 '33.73 "at 02.00 WIB and Azimuth Qibla 2940 31 02.25", after knowing the azimuth of the star and the azimuth of the qibla we calculate the difference in the azimuth with the different formula azimuth = azimuth qibla - star azimuth (294o 3102.25 "- $153^{\circ} 44$ 33.73" = 140 46 28.52 ").practice illustration:

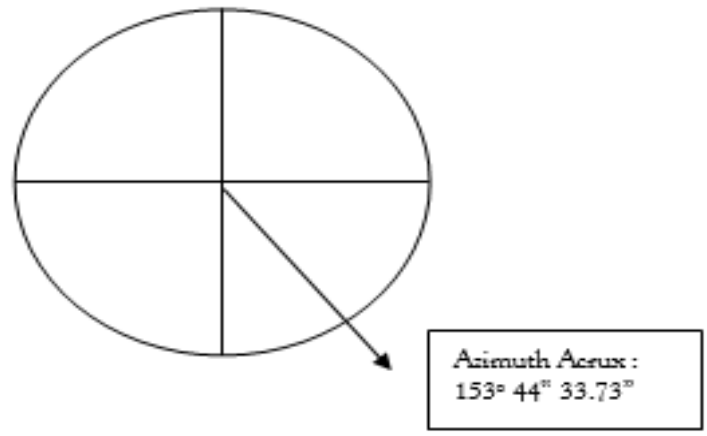

Pic.5. The Position of Azimuth Acrux Star 
From the image, it is known that the position of the star Acrux at $02.00 \mathrm{WIB}$ was at azimuth $153 \circ 4433.73$ ".

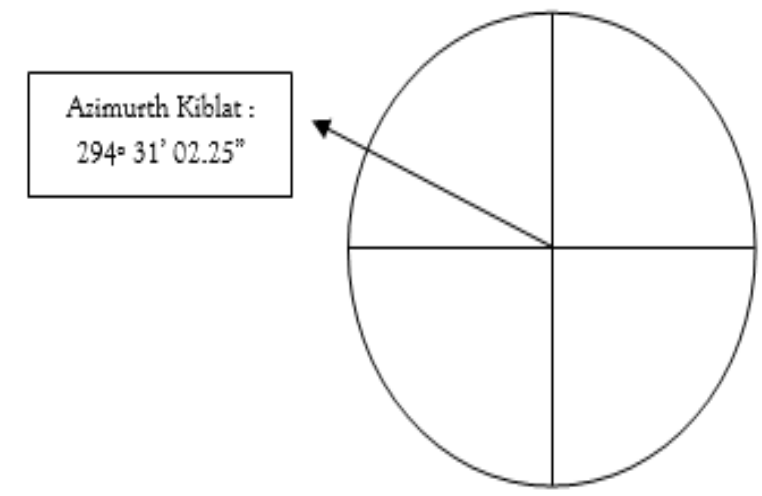

Pic.6. The Position Azimuth of the Qibla of a Place

From the image, it is known that the position of the Qibla direction is at azimuth 294\% $3102.25 "$

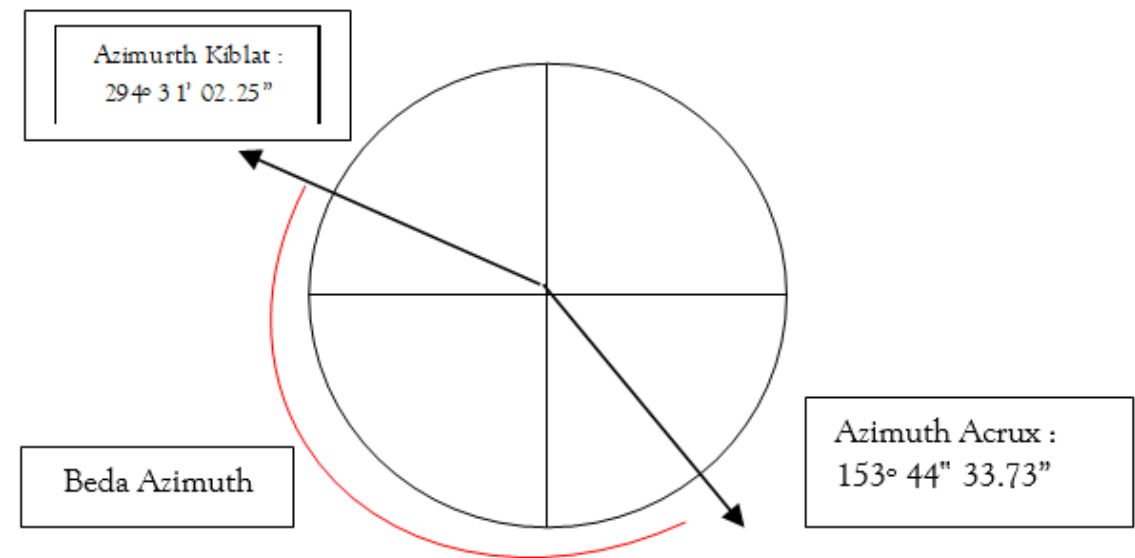

Pic.7. The Difference between Acrux Star Azimuth and Qibla Azimuth

From this image, the azimuth of the Qibla and the azimuth of the Acrux star is combined, therefore to find out the direction of the Qibla, it is only necessary to look for the difference in the azimuth of the two azimuths. From the result of the combination, the azimuth difference is $140^{\circ} 4628.52$ "

So to calculate the star GHA $=$ SHA star + GHA Aries. ${ }^{45}$

${ }^{45}$ GHA Aries should not be any different from a star, but as Hipparchus noted long ago that the earth shakes, its axis is doing a full circle of about 26,000 years which means that the first point of Aries slowly drifts across the background of the star, making a full circlein 26,000 years. This is called the first point of Aries because it

Al-Hilal: Journal of Islamic Astronomy, Vol. 2, No. 2, Tahun 2020

p-ISSN : 2775-1236; e-ISSN : 2775-2119 


$$
\begin{aligned}
\text { Difference Azimuth } & =\text { Azimuth Qibla }- \text { Star Azimuth } \\
& =294 \text { o } 3102.25^{\prime \prime}-153^{\circ} 4433.73^{\prime \prime}=140^{\circ} 4628.52^{\prime \prime}
\end{aligned}
$$

In addition to using the azimuth of the Acrux star, we can test the accuracy of determining the direction of the Qibla by using the azimuth of the Sun which has been considered quite accurate. The author provides an example of a calculation using the azimuth of the sun with the following formula: ${ }^{46}$

Example of solar azimuth calculation on December 13, 2017 at 09.35 WIB at Kongkow Carsem BPI stall with latitude -6 5933.3 "latitude and longitude 110 21 22.2" east longitude and azimuth qibla 294 3102.25 "UB. To calculate the azimuth of the Sun, include:

Known:

Shooting time: 09.35 WIB

Declination : $-23^{\circ} 0844.09$ "

Equation : :00 $0553.99 "$

1) Calculate the solar time angle

$$
\mathrm{t}=(\mathrm{LMT}+\mathrm{e}-(\lambda \mathrm{d}-\lambda \mathrm{x}): 15-12) \mathrm{x} 15
$$$$
=-29 \circ 2507.95 "
$$

2) Calculate the sun's height

$\operatorname{Sin} \mathrm{h}=\sin \phi \mathrm{x} \sin \delta+\cos \phi \mathrm{x} \cos \delta \cos \mathrm{t}$

$$
=30^{\circ} 4007.95^{\prime \prime}
$$

3) Calculate the zenith distance of the sun

4) $\operatorname{Cos} z \mathrm{~m}=\sin \phi \mathrm{x} \sin \delta+\cos \phi \mathrm{x} \cos \delta \cos \mathrm{t}$

is the point where the sun crosses the equatorial plane on its way from the Southern hemisphere to the North (around March 21) and it happens to the fallen Zodiac sign Aries.

${ }^{46}$ Hambali, "Ilmu Falak," 2011.

Al-Hilal: Journal of Islamic Astronomy, Vol. 2, No. 2, Tahun 2020 p-ISSN : 2775-1236; e-ISSN : 2775-2119 


$$
=33 \circ 3620.34 "
$$

5) Knowing the direction of the Sun and the azimuth of the Sun

$\operatorname{Cotan} A=\tan \delta \cos \phi x: \sin t-\sin \phi x: \tan t$

$$
=-57^{\circ} 0335.32 ”
$$

To get the Azimuth of the Sun, you can use the following conditions:

If $\mathrm{A}=\mathrm{UT}(+)$, then Sun Azimuth = A (fixed).

If $\mathrm{A}=\mathrm{UB}(+)$, then the Azmiuth of the Sun $=360^{\circ}-\mathrm{A}$.

If $A=$ ST $(-)$, then the Azimuth of the Sun $=180^{\circ}-A$. With the value of $A$ being positive.

If $\mathrm{Ab}=\mathrm{SB}(-)$, then Sun Azimuth $=180^{\circ}+\mathrm{Ab}$. With the value of A positive

6) Knowing the Sun Azimuth

Azimuth Star $=180^{\circ}-$ A.

$$
=122 \circ 5624.68 "
$$

7) Different Azimuth

Different Azimuth $=$ Azimuth Qibla - Sun Azimuth

$$
=171^{\circ} 3437.38^{\prime \prime}
$$

\section{C.7. Analysis of the Azimuth of the Acrux Star as a Reference for Determining the}

\section{Direction of the Qibla}

At this time, the method of determining the direction of the Qibla that is often used by the general public and which is considered the most accurate is the method of determining the direction of the Qibla using the Sun reference, either using the azimuth of 
the Sun using the theodloite, istiwaain, or solar qibla rashdulalthough this method has its drawbacks when it is cloudy.this method cannot be implemented.

Determining the direction of the Qibla using the azimuth of the Acrux star is one way to determine the direction of the Qibla at night when observations cannot be made during the day because it is cloudy or rainy. This Acrux star can be used as a reference for determining the direction of the Qibla because the azimuth value can be calculated.

To find out the azimuth value of these objects at certain hours and days, you can use several celestial body applications such as: Stellarium, ${ }^{47}$ Sky Map, ${ }^{48}$ Starry Night, ${ }^{49}$ Nautical Almanac, ${ }^{50}$ and others. We can download everything through the google play store, which is directly mentioned in the application the azimuth of the object.

In this case, the authors analyze and calculate the azimuth value of the Acrux star with the help of the data contained in the Nautica Almanac. After the authors calculate the azimuth of the star, compare the results contained in the Stellarium application. For example, the author calculates the azimuth of the star Acrux on December 13, 2017 at 03.00 WIB at the Kongkow Carsem BPI shop with latitude -6 5933.3 "latitude and longitude of place 110 21 22.2" East Longitude

1) The result of calculating the azimuth of the Acrux star

GHA star: $194^{\circ} 4818^{\prime \prime}$

LHA star: 305०09 40.2 "

Star height: 210 2948.58 "

SHA star: $173^{\circ} 06.0$

Star deck: -63011.5

RA star: 120 2736 "

${ }^{47}$ Stellarium is a free open source planetarium for computers. This software shows the sky realistically in 3D, just like what you see with the naked eye, binoculars or telescope. Stellarium can be used on Android phones.

${ }^{48}$ Sky Map is a sky map application that shows us celestial objects such as stars, planets, and so on. We can also use Sky Map on Android phones.

${ }^{49}$ Starry Night is an application commonly used by the 'badan hisab' (for date calculations) to see the determination of the beginning of the month, and others. This application is only limited to computer devices only

${ }^{50}$ Nautical Almanac is an application used by sailors to see the azimuth, height of these objects and others. This application can be used on Android phones .

Al-Hilal: Journal of Islamic Astronomy, Vol. 2, No. 2, Tahun 2020 p-ISSN : 2775-1236; e-ISSN : 2775-2119 
Direction of the stars: 230 2045.12 "

Star azimuth: $156^{\circ} 3914.88^{\prime \prime}$

2) Acrux star azimuth results using the Stellarium app

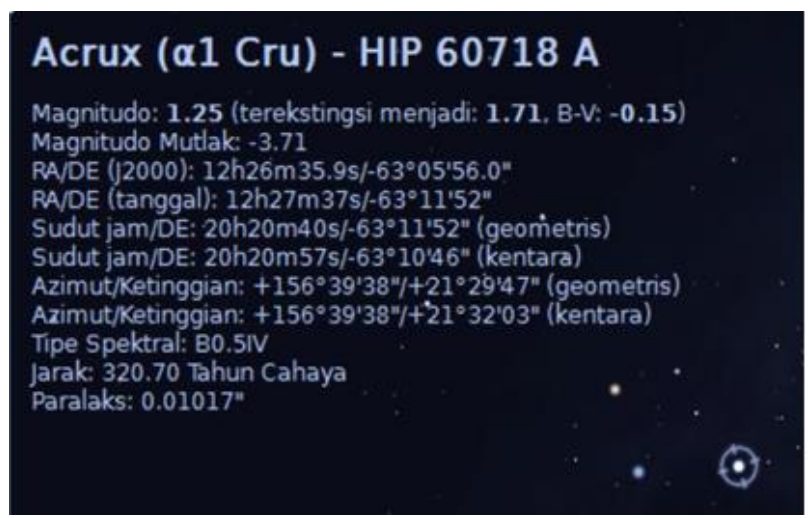

Pic. 8. Result of Acrux Azimuth by Stellarium Application

\begin{tabular}{lc}
\hline Own Calculations & Stellarium \\
\hline $156^{\circ} 39^{\prime} 14.88^{\prime \prime}$ & $156^{\circ} 39^{\prime} 38^{\prime \prime}$ \\
\hline Table 3. Comparison of the azimuth values of Acrux stars
\end{tabular}

Table 3. Comparison of the azimuth values of Acrux stars

The azimuth value obtained is not too much different, only in seconds. And to apply it to Theodolite it doesn't really matter because in Theodolite the difference can reach the order of 5 seconds .

In this research, the writer made five observations, three times at night using the Acrux star, and two observations during the day using sunlight as a determination of the Qibla direction. Qibla measurements were carried out at the Kongkow Carsem BPI stall with -659' 33.3 "south latitude and 10॰21'22.2" east longitude

1) The first measurement with the star Acrux

Measurement of the Qibla with the Acrux star was carried out on December 10, 2017, the data are as follows:

\begin{tabular}{lllll}
\hline Acrux Star & 10 December 2017 & $\begin{array}{l}12 \\
2017\end{array}$ & December & 13 \\
& & 2017 & December \\
& & & \\
\hline Star Shooting Time & 03.00 WIB & 02.00 WIB & 03.45 WIB \\
\end{tabular}

Al-Hilal: Journal of Islamic Astronomy, Vol. 2, No. 2, Tahun 2020

p-ISSN : 2775-1236 ; e-ISSN : 2775-2119 


\begin{tabular}{|c|c|c|c|}
\hline Acrux Star Rising Time & $23^{\circ} 59^{\prime} 37.23^{\prime \prime}$ & $23^{\circ} 51^{\prime} 39.45^{\prime \prime}$ & $23^{\circ} 47^{\prime} 48.11^{\prime \prime}$ \\
\hline Acrux Star Sinking Time & 13० 41'26.61" & 13。 33'37,59” & 13० 29'38.79” \\
\hline SHA (Sidereal Hour Angle) & $173^{\circ} 06.0^{\prime}$ & $173^{\circ} 06.0^{\prime}$ & $173^{\circ} 06.0^{\prime}$ \\
\hline $\begin{array}{lll}\text { GHA } & \text { (Greenwich } & \text { Hour } \\
\text { Angle) } & & \\
\end{array}$ & 191'50'54” & $178^{\circ} 46^{\prime} 42^{\prime \prime}$ & 194' 58’ 38.13” \\
\hline LHA (Local Hour Angle) & $302^{\circ} 12^{\prime} 16.2^{\prime \prime}$ & 289॰08'04.2” & $305^{\circ} 19^{\prime} 40.33^{\prime \prime}$ \\
\hline Dek (Deklination) & $-63^{\circ} 11.5^{\prime}$ & $-63^{\circ} 11.5^{\prime}$ & $-63^{\circ} 11.5^{\prime}$ \\
\hline Height Of Acrux Star & 20॰ 19’04.62” & 14ㅇ $47^{\prime} 48,29^{\prime \prime}$ & 21. 33’ 48.75” \\
\hline Zenith Distance Acrux Star & $69^{\circ} 40^{\prime} 55.38^{\prime \prime}$ & $75^{\circ} 12^{\prime} 11,71^{\prime \prime}$ & $68^{\circ} 26^{\prime} 11.25^{\prime \prime}$ \\
\hline Azimuth Star Acrux & 155' 59’ 14.04” & 153 51'04.14" & $156^{\circ} 41^{\prime} 36.87^{\prime \prime}$ \\
\hline Azimuth Qibla & 294 31'02.06” & 294 31'02.06” & 294o 31'07.91" \\
\hline Different azimuth & 138 31'48.21" & 140。 39’ 58.11” & $137^{\circ} 49^{\prime} 31.23 ”$ \\
\hline
\end{tabular}

Table 4. Acrux Star data at the time of observation 10, 12 and 13 December 2017

Measurements on December 10 with the star Acrux failed to take, according to the authors this is due to weather pollution where it rained in the afternoon until the night resulted in a cloudy sky. but what the author observed was that at 21.00 WIB the author saw several stars in the sky, after waiting until the Acrux star appeared, one star could not be seen because the sky was cloudy until dawn.

The second measurement with the star Acrux on 12 December was successful. At that time, the position of the sky was very supportive to make observations where the sky was clear and could see many stars. and the Acrux star is very easy to identify because of its shape that resembles a kite.

As for the third observation, the author is in a different place from the previous observation. The third observation was carried out in Ringinsari 2 with the coordinates of latitude -6o 5938 "South Latitude and longitude $110^{\circ} 21$ 02.2" East 
Longitude. Measurement of the Qibla with the star Acrux was carried out on December 13, 2017.

2) Measurement by Solar azimuth

The first measurement of Qibla with sunlight was carried out on December 13, 2017, with the following data:

\begin{tabular}{|c|c|c|}
\hline Solar Data & 13 Desember 2017 & 12 Desember 2017 \\
\hline Shooting Time & $09.35 \mathrm{WIB}$ & $08.05 \mathrm{WIB}$ \\
\hline $1^{\text {st }}$ Deklination & $-23^{\circ} 08^{\prime} 44^{\prime \prime}$ & $-23^{\circ} 04^{\prime} 17^{\prime \prime}$ \\
\hline $2^{\text {nd }}$ Deklination & $-23^{\circ} 08^{\prime} 44^{\prime \prime}$ & $-23^{\circ} 04^{\prime} 29^{\prime \prime}$ \\
\hline $1^{\text {st }}$ Equation of Time & $0 \circ 05^{\prime} 54^{\prime \prime}$ & $0 \circ 06^{\prime} 24^{\prime \prime}$ \\
\hline $2^{\text {nd }}$ Equation of Time & $0.05^{\prime} 53^{\prime \prime}$ & $0 \circ 06^{\prime} 23^{\prime \prime}$ \\
\hline Height Of Sun & $30^{\circ} 40^{\prime} 07.95^{\prime \prime}$ & $53^{\circ} 02^{\prime} 57.8^{\prime \prime}$ \\
\hline Zenith Distance Of Sun & $33^{\circ} 36^{\prime} 20.34^{\prime \prime}$ & $53^{\circ} 22^{\prime} 11.29^{\prime \prime}$ \\
\hline Azimuth Qibla & 294' 31'02.06" & 294'31'07.91" \\
\hline Azimuth Of Sun & $122^{\circ} 56^{\prime} 24.68^{\prime \prime}$ & $113^{\circ} 51^{\prime} 12.17^{\prime \prime}$ \\
\hline Different Of azimuth & 171'34'37.38" & 180'39’ 55.75" \\
\hline
\end{tabular}

Table 5 . Data on the Sun at the time of observation on December 12 and 13

Measurements using the azimuth of the sun have been successfully carried out, and the measurement of the direction of the flash is the accuracy of the measurement of the Qibla direction using the Acrux star azimuth reference.

Al-Hilal: Journal of Islamic Astronomy, Vol. 2, No. 2, Tahun 2020

p-ISSN : 2775-1236; e-ISSN : 2775-2119 


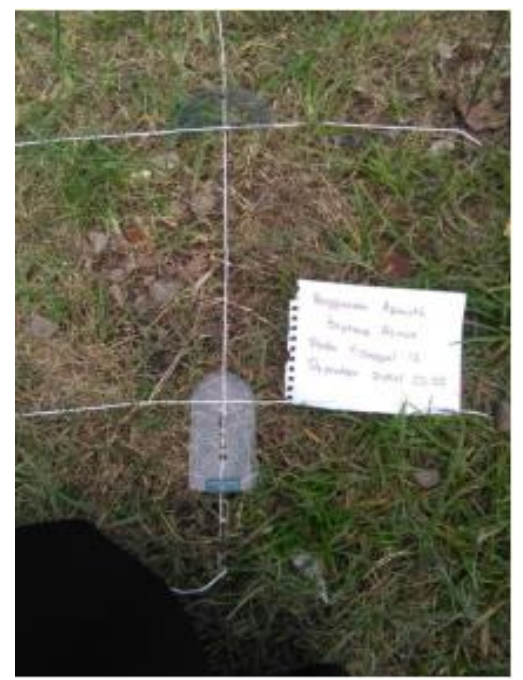

Pic.9. Qibla direction using the azimuth of the star Acrux

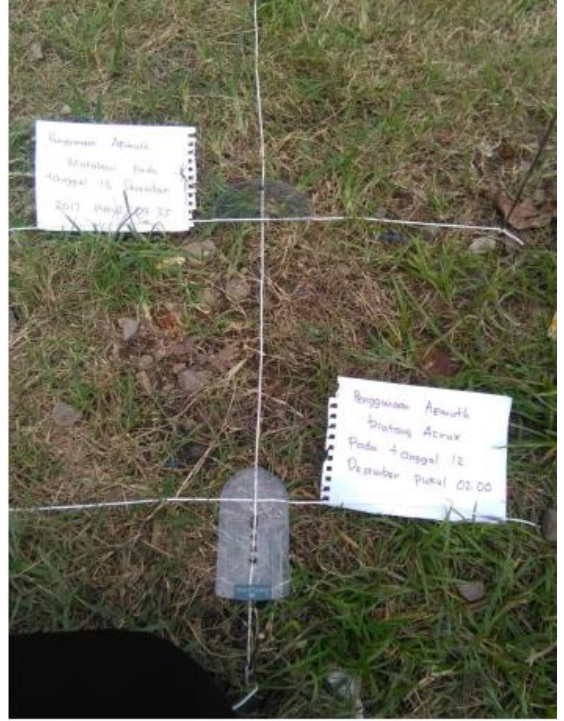

Pic.10. Qibla direction using Acrux star azimuth and Sun azimuth

The results of the first comparison using the azimuth of the Acrux star and the azimuth of the Sun have a difference of $0.2 \mathrm{~cm}$. To find out the flexibility, using a formula, namely Tan $K=$ difference $/$ length so that $\operatorname{Tan} K=0.2 / 50 \mathrm{~cm}=0 \circ 13$ 45.05 ". So the slope is 0o $1345.05 "$.

3) The fifth measurement using the azimuth of the sun

The author's fifth observation uses the same place as the fourth observation. Measurement of the Qibla with the star Acrux was carried out on December 12, 2017, the data are as follows: 


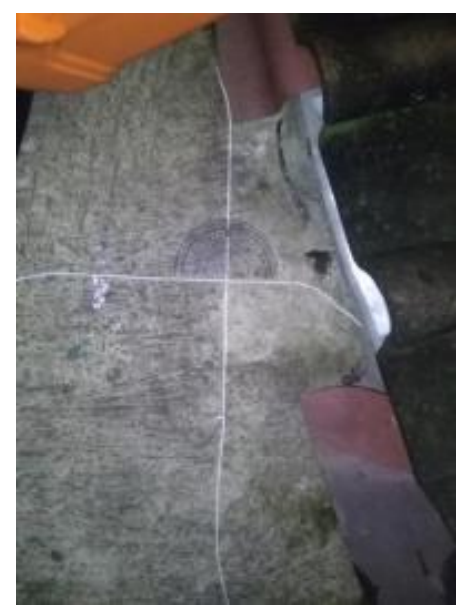

Pic.11. Qibla direction using Acrux star azimuth

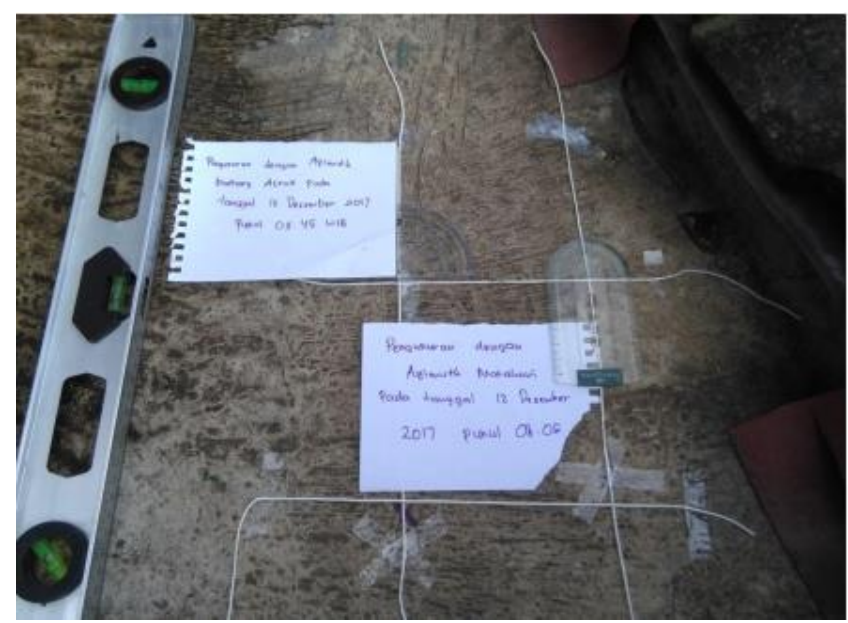

Pic.12. Qibla direction using Acrux star azimuth and solar azimuth

The results of the first comparison using the azimuth of the Acrux star and the azimuth of the Sun have a difference of $0.1 \mathrm{~cm}$. To determine the flexibility using the formula, namely Tan $\mathrm{K}=$ difference $/$ length so that Tan $\mathrm{K}=0.1 / 45 \mathrm{~cm}=$ 0 0738.37 ". So the slope is 0 o 0738.37 ”. From the comparison of the two studies, the results of skewness are still at the permitted skewness, where in Indonesia the maximum limit of skewness is $0^{\circ} 24$.

From all the research results, the authors compare the Qibla line using the reference for determining the direction of the Qibla using the Sun's azimuth with the Acrux star azimuth. It looks like this results in a very small difference, because 
they are both stars so the accuracy is relatively the same, howeveraiming at the Sun is easier because the objects in the sky are very clear than the Acrux star which must be searched first and another difference is that the azimuth of the Sun is used during the day and the azimuth of the Star Acrux is used at night.

\section{Conclusion}

Based on the discussion and analysis above, it can be concluded that the Gubug Penceng can be used as a reference in determining the direction of the Qibla. In this case, we can choose one of the bright stars to determine the azimuth value, then measure the difference between the azimuth and the Qibla. This is very possible because they are both at the coordinates of the horizon. The measurement result data is quite accurate. Compared with the measurement results using the azimuth of the Sun, the difference does not exceed 00 24. This means that the hut can be an alternative solution in determining the direction of the Qibla if it is cloudy or rainy when you want to use the Sun as a reference for determining the direction of the Qibla.

\section{E. BIBLIOGRAPHY}

Adieb, Muhammad. "Studi Komparasi Penentuan Arah Kiblat Istiwaaini Karya Slamet Hambali Dengan Theodolite.” IAIN Walisongo, 2014.

Al-Jaziry, Abdurrahman bin Muhammad Awwad. "1699, Kitabul Fiqh 'Ala Madzahibil Arba'Ah.” Beirut: Dar Ihya'At Turats Al Araby, n.d.

Arifin, Zainul. Ilmu Falak: Cara Menghitung Dan Menentukan Arah Kiblat, Rashdul Kiblat, Awal Waktu Shalat, Kalender Penanggalan, Awal Bulan Qomariyah,(Hisab Kontemporer). Penerbit Lukita, 2012.

Azhari, Susiknan. Ensiklopedi Hisab Rukyat. Pustaka Pelajar, 2005.

Dahlan, Abdul Aziz. "Ensiklopedi Hukum Islam.” Jakarta: Ichtiar Baru Van Hoeve, 1996.

Fahrin, Fahrin. "Qibla Laser Sebagai Alat Penentu Arah Kiblat Setiap Saat Dengan Menggunakan Matahari Dan Bulan.” IAIN Walisongo, 2014.

Hambali, Slamet. "Ilmu Falak." Semarang: Program Pascasarjana IAIN Walisongo Semarang, 
2011.

_. Ilmu Falak. Semarang: UIN Walisongo, 2018.

Izzuddin, Ahmad. Ilmu Falak Praktis: Metode Hisab-Rukyat: Praktis Dan Solusi Permasalahannya. Pustaka Rizki Putra, 2012.

Khozin, Muhyiddin. "Ilmu Falak Dalam Teori Dan Praktik.” Yogyakarta: Buana Pustaka, 1996.

Nasution, Harun. “Ensiklopedi Hukum Islam.” Jakarta: Djambatan, 1992.

Ni’am, M Ikhtirozun. “Arah Kiblat Di Planet Mars.” Al-Marshad: Jurnal Astronomi Islam Dan Ilmu-Ilmu Berkaitan 2, no. 1 (2017).

RI, Departemen Agama. “Al-Qur'an Dan Terjemahnya.” Semarang: Toha Putra, 1989.

Rojak, Encep Abdul, Amrullah Hayatudin, and Muhammad Yunus. "Koreksi Ketinggian Tempat Terhadap Fikih Waktu Salat: Analisis Jadwal Waktu Salat Kota Bandung.” Al-Ahkam 27, no. 2 (2017): 241-66.

Romdhon, M Ali. "Studi Analisis Penggunaan Bintang Sebagai Penunjuk Arah Kiblat Nelayan (Studi Kasus Kelompok Nelayan 'Mina Kencana’ Desa Jambu Kecamatan Mlonggo Kabupaten Jepara).” IAIN Walisongo, 2012.

Sampulawa, Abdullah. "Penentuan Arah Kiblat Menggunakan Azimuth Planet." Skripsi Fakultas Syari'ah dan Hukum UIN Walisongo Semarang, 2016.

Sarruji, Imam. "Penentuan Arah Kiblat Menggunakan Azimuth Bintang Dan Planet." Skripsi 147 (2016): 11-40.

Sudibyo, Muh. "Sang Nabipun Berputar: Arah Kiblat Dan Tatacara Pengukurannya." Solo: Tinta Media, 2011.

Sugiyono, Prof. "Memahami Penelitian Kualitatif.” Bandung: Alfabeta, 2005.

Sutantyo, Winardi. “Bintang Bintang Di Alam Semesta.” Penerbit ITB, Bandung, 2010.

Al-Hilal: Journal of Islamic Astronomy, Vol. 2, No. 2, Tahun 2020

p-ISSN : 2775-1236; e-ISSN : 2775-2119 